UDC: $504: 598.2+599.4+502$

\title{
PROTECTING BIRDS AND BATS IN BUILDINGS UNDERGOING THERMAL INSULATION IMPROVEMENTS - PROCEDURES AND PRACTICE IN POLAND
}

\author{
Karolina Jamska \\ Bewik - Bydgoska Grupa Ogólnopolskiego Towarzystwa Ochrony Ptaków \\ ul. Bielicka, 1/20, 85-135 Bydgoszcz, Poland \\ e-mail: karolina.jamska@gmail.com
}

Due to a progressive degradation of natural environment, more and more animal species try to live in the anthropogenic conditions. Some animals are so well adapted to the new conditions that both their populations and areas of occurrence increase. Some bird and bat species that use the building as a place for nesting, breeding and hibernation are good examples of such successful adaptation. In recent years, the old buildings that are full of various cracks and openings attractive to the animals, are intensively renovated and modernized. As a result, birds and bats, although protected by law, lose their habitats and often lives, which in turn threatens a stability of their populations. Therefore, there is a strong drive to protect wildlife species and their habitats in buildings. As a result, standards and practical guidelines have been developed for planning and implementing building renovations, as well as appropriate compensating solutions have been designed for each species. The purpose of this paper is to review basic knowledge and experience in the protection of animals in buildings in towns and cities in Poland.

Keywords: bats and birds in buildings, thermal insulation of buildings, protection of bats and birds.

\section{INTRODUCTION}

Even in the 1990s the landscape of Polish cities was dominated by the apartment blocks built of concrete slabs and old, often pre-war residential buildings. Their poor construction design and advanced age has been the main reason for the large energy losses and high operating costs, especially during winter months. Therefore, the last two decades have seen a boom in construction and renovations projects involving the building thermal insulation improvements throughout the country. Although these projects are favorable from the economical and environmental point of view, they also have negative effect on local wildlife. Sealing or blocking unwanted holes, slots and openings in renovated buildings have been resulting in large losses of natural habitats for birds [3, 23], and bats [22]. During the renovations these habitats are destroyed [22], and the animals thrown out of the occupied areas or sometimes walled up alive [28], resulting in the declines of their populations [5-9, 11, 26, 29]. Public protests against these practices have brought some positive changes with respect to the animal protection in buildings [28].

ISSN 1996-4536 (print) • ISSN 2311-0783 (on-line) • Біологічні Студії / Studia Biologica • 2014 • Том 8/№1 • C. $205-216$ 
Work has begun on the development of guidelines and standards of conduct during building renovations including proposals for environmental compensation methods as well as changing local laws to assist and facilitate animal protection [20].

The purpose of this article is to review the basic knowledge and experience of animal protection in buildings in Poland.

\section{ANIMAL SPECIES INHABITING BUILDINGS}

In Poland, the buildings are used primarily by birds, especially rock and hole nesting species, as breeding sites and by bats as places of hibernation and refuge of breeding colonies [22]. Among animals inhabiting buildings are those belonging to both the common as well as the rarest species. All however, in accordance with the Polish law, are protected species.

BIRDS. Common Swift Apus apus has become the symbol of bird protection in buildings. In Poland, this species nesting habitats are almost exclusively limited to buildings $[6,9,29]$, so the total elimination of the anthropogenic breeding sites in the worst case can lead to the extinction of species in the country. This bird species was originally nesting in the rocky habitats and sometimes in the hollows of trees in open areas or at the edges of the forests [29] and therefore now chooses for its breeding sites mainly the high-rise buildings [23], which perfectly mimic its natural habitat [24]. It uses buildings' roof attics and cavities, and various other slots and opening for its new habitats.

House Sparrow Passer domesticus is also strongly associated with human building structures $[6,9]$. Sparrow's ecological adaptability in the selection of nesting sites is very high. This bird species willingly adapts every available open slot or cranny for its habitat [26] for example, under the sills, gutters and roof tiles, between the slabs, in a breach in the walls, etc. Sometimes, it builds its nest in vines growing on the walls of houses [4].

Jackdaw Corvus monedula is another species that is now largely dependent on man for its current habitats [6,9]. Originally inhabited hollowed trees [7], but as they started to disappear from the landscape, jackdaws began to adopt the anthropogenic habitats $[7,8]$. Due to its considerable size finding a suitable refuge is not easy. These birds can now be spotted in some roof attics and roof structure cavities as well as other bigger size niches and openings. Jackdaws also inhabit the building chimneys [7], 19], which typically leads to conflicts with humans and may also endanger the animals.

Kestrel Falco tinnunculus is a bird of prey and about $20 \%$ of its population in Poland dwells in the cities [1, 2], especially in the western parts of the country. It nests in taller buildings $[18,23,25]$ in both the roof attics and its cavities, or directly on the roofs, and even in flower pots of the balconies. This bird also likes to build their nests in towers and facade sculptures of the churches.

Feral pigeon Columba livia domestica has the least habitat requirements of all of the mentioned species of birds. It prefers places with free access such as large roof openings and cavities (over $10 \mathrm{~cm}$ in diameter), but also inhabits balconies, windowsills, flower pots, roof gutters [20] and park trees. This bird is often considered a nuisance species because of significant amount of droppings left over around its nesting grounds.

In addition to the species described above, there are also other birds inhabiting buildings such as: House Martin Delichon urbicum [11, 23], Great Tit Parus major and Blue Tit Cyanistes caeruelus, Little Owl Athene noctua, Peregrine Falcon Falco peregrinus and Black Redstart Phoenicurus ochruros [20].

ISSN 1996-4536 (print) • ISSN 2311-0783 (on-line) • Біологічні Студії / Studia Biologica • 2014 • Том 8/№1 • C. $205-216$ 
Currently, the poor practices employed during building renovations can be blamed for a clear decrease in the populations of bird species strongly associated with building habitats such as swifts, sparrows and jackdaws [13, 20]. For other common bird species the elimination of breeding sites in buildings may not matter on a national scale. However, we cannot completely ignore such actions for humanitarian reasons, due to their negative effects on the individual animals. Paradoxically, for some birds, the renovations of buildings create new opportunities for settlement. One example is a Great Spotted Woodpecker Dendrocopos major, which happens to drill hollows in the buildings styrofoam wall insulation or a House Martin, which gains more favorable and deeper window recesses. Unfortunately, in such cases, the birds are often intentionally and illegally removed from the buildings.

BATS. Most species of bats, which can be regularly found in Poland inhabit buildings [21]. Unlike birds, which, apart from a few exceptions, such as urban pigeons, reside in buildings only during the breeding season [20], bats use them in all times throughout the year. In spring and summer they look for safe havens for their breeding colonies, in autumn they use them for mating places and in winter for hibernation. Each of these tasks requires different conditions. Different species also have special preferences in the selection of their shelters. Therefore, the variety of locations used by these animals is very high. They can be found hidden in the narrow and deep crevices, attics, in basements, around windows and door frames and hanging freely on the outer walls of buildings. For this reason, the planning of building renovations in a manner safe for bats is much more difficult than in the case of birds, which are more predictable and easier to observe. The most common bat species inhabiting buildings are:

Pipistrelle bat Pipistrellus spp. are the smallest bat species living in Poland. Because of their size they can squeeze into even the narrowest of crevices like those between the window frames or under roof tiles. They use (especially the tiny Common Pipistrelle Pipistrellus pipistrellus) mostly above-ground parts of buildings, both for breeding and hibernation [22].

Serotine Bat Eptesicus serotinus is one of the most synanthropic species of bats. Sometimes their population is greater in the high density building areas, than in suburban areas [17]. Due to their significant size, these bats can be found mainly in the older buildings, typically full of larger openings and cavities, where they dwell throughout the year [22].

Common Noctule Nyctalus noctula is one of the largest native species of bats. They are typically associated with the forested areas, their preferred habitat, but they are increasingly spotted in cities inhabiting, for example, the cavities under the damaged layers of building insulation [21]. Although these bats are migratory species and in winter usually move to the warmer parts of Europe, but they are often found in Polish cities hibernating, among others, in the cracks and crevices of building walls [10, 22].

There are many other bat species regularly found in the buildings, including Longeared Bat Plecotus spp., Horseshoe Bat Rhinolophus spp. [21], Parti-coloured Bat Vespertilio murinus [22], and Northern Bat Eptesicus nilssonii [16, 22].

\section{LEGAL ASPECTS}

The principles of practice and conduct during building renovation projects which may threaten the wildlife, have been incorporated into the Polish law relatively recently [6]:

ISSN 1996-4536 (print) • ISSN 2311-0783 (on-line) • Біологічні Студії / Studia Biologica • 2014 • Том 8/№1 • C. $205-216$ 
- Protection of nature (Act of April 16, 2004, Journal of Laws (JL) 2004 No. 92, Item 880);

- Animal protection (Act of August 21, 1997, JL 1997 No. 111, Item 724);

- Construction Law (Act of July 7, 1994, JL 1994 No. 89, Item 414);

- Criminal Code (Act of June 6, 1997, JL 1997 No. 88, Item 553).

Violation of these rules threatens the criminal penalties and immediate suspension of renovation work, and thus, financial losses for the building owners and contractors. Besides the animals themselves, their habitats, breeding and nesting grounds, and eggs are also protected (Ministry of Environment, Regulation of October 12, 2011 on the protection of animal species, JL No. 237, Item 1419). In the light of the legal provisions, the building inhabited by birds or bats is deemed as their habitat [22], and it can be destroyed only after filing an application and obtaining the approval of the Regional Director of Environmental Protection (RDEP). To obtain such consent, the subject of the application must be first identified, including the animal species inhabiting the building and the size of their populations. To this end, investors should request a report drawn up by a professional naturalist [22]. The submission of expertise is not a requirement of national law, but only a recommended practice, which is why some municipal governments such as Milanówek [20], Poznan, and some districts in Warsaw are implementing it as a record of municipal law. A Regional Director of Environmental Protection (RDEP), to authorize the destruction of habitat, typically determines its specific terms and conditions, which among others include: the scope of environmental compensation, possible dates for planned construction work, and protection methods of habitats targeted for destruction to ensure the safety of animals during the renovation work.

\section{RENOVATION WORK AND ITS PLANNING}

Any building renovations, which may threaten the destruction of habitats of protected animals, should be carefully planned at least a year before the commencement of any work [22]. This practice is rarely used in Poland and only recently the pressure of public opinion and non-governmental organizations enforces desirable rules of conduct. Unfortunately, these desirable practices are almost exclusively limited to the larger cities [6]. One year period provides a good basis for the observation of birds and bats throughout the seasons and allows for the accurate identification of all species inhabiting the property and estimation of their populations. The best times for carrying the building renovations and construction work are those outside of the animal seasonal habitation periods when animals normally occupying the building are not present [21]. In case this is not possible, all holes, cracks and crevices should be either blocked prior to the animal settlement or equipped with flexible flap gates opening only one way to the outdoors. The second solution will allow animals to leave the habitat and at the same time prevent them from returning to it. However, it is very important to note that this solution can be used only outside of the birds breeding and the bats reproductive season. Otherwise, the parents leaving their young inside will not be able to return to care for them.

During the building renovation projects special precautions should be taken as to not to disturb the animal breeding and hibernation [22], and the more to kill them or destroy their eggs and nests. After seeing that a bird or a bat managed to take a possession of a habitat in a secured area, all work in the habitat's vicinity should be immediately stopped and it can only be resumed after the animal leaves this habitat. Engaging qualified ornithologists or chiropterologists to supervise and monitor the building

ISSN 1996-4536 (print) • ISSN 2311-0783 (on-line) • Біологічні Студії / Studia Biologica • 2014 • Том 8/№1 • C. $205-216$ 
renovation work is very helpful to assure compliance with the applicable laws and best practices. If the building owner or his contractor fails to comply with proper procedures and endangers the life of affected animals, the District Inspector of Building Control has a legal right and obligation to order an immediate suspension of all work.

\section{COMPENSATION}

Compensation of habitats destroyed during the renovation projects plays the critical role in protecting of animal species inhabiting the buildings. The compensation success and its effectiveness are measured by the ability of displaced animals to return to their building habitats.

LEAVING HABITATS INTACT. The best compensating solution is to leave any holes and cavities, which were previously occupied by birds and bats, open [20]. This solution is now most commonly used in situations where birds occupy roof vent openings. During the building renovation, these openings are furnished with either ceramic or PVC extension tubes [13]. It is an inexpensive, most durable, while at the same time the best solution. Animals do not need to get accustomed to the new conditions, and the risk they leave their habitat is minimized. It is important, however, that these inlet tubes have rugged inner surfaces so the birds will not slip inside them and have an appropriate diameter for the various species. This solution is currently used mostly for Common Swift (tubes with a diameter of $50-80 \mathrm{~mm}$ ) and Jackdaw. The nesting boxes recommended for Jackdaw have entry holes with a diameter of minimum of $80 \mathrm{~mm}$ (usually 85 $\mathrm{mm}$ ) [19]. However, my preliminary observations show that these birds, which are strongly attached to their habitats [19], leave their former dwellings in the buildings where during the renovation the entry tubes of such a small size have been installed. So most likely a diameter of 80 or even $85 \mathrm{~mm}$ is too small in situations where the pathway for these birds has been increased from just a few $\mathrm{cm}$ as in the nesting boxes to tens of centimeters travelled inside the tubes in the renovated buildings. Therefore, the safest option for Jackdaw is to install inlet tubes with a larger diameter of $100 \mathrm{~mm}$. This would not only provide an easier access to the bird's nesting sites, but would also minimize the negative effects of potential contractor's errors when the installed tubes are a few millimeters smaller than the recommended by RDEP. Such errors have been reported in Bydgoszcz several times already and while the renovation work appeared to comply with the required guidelines in the end the birds have lost their habitat (Fig. 1).

Fig. 1. Inlet tubes installed in the roof structure inhabited by Jackdaws should provide an easy access to the birds' habitat after the renovation - in this building (left - before renovation; right - after renovation) the Jackdaws lost their habitat due to the installation of smaller diameter tubes than the recommended $93 \mathrm{~mm}$

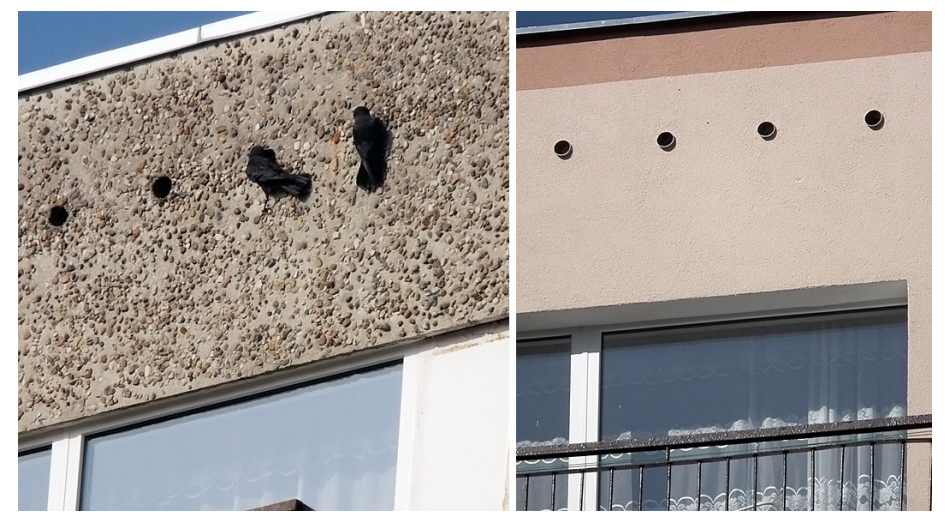

ISSN 1996-4536 (print) • ISSN 2311-0783 (on-line) • Біологічні Студії / Studia Biologica • 2014 • Том 8/№1 • C. $205-216$ 
In the case of insulated roofs a consideration should be given to the type of insulation used. Mineral wool or cellulose fibers are the most widely used insulating materials for this purpose in Poland. Although there is an ongoing discussion in Poland about the dangers of these materials, to date there are no records of their adverse effects on health or life of animals. On the contrary, my numerous observations in Bydgoszcz, Warsaw and Lubsko (over 20 apartment blocks in five housing developments, including eight insulated roofs with an operating history of at least five years) show that birds are willing to exploit these altered habitats and successfully raise their young in the new environments. Currently, it is unknown whether the young leave their nests completely healthy and/or unaffected, but until the long term impact of these materials on the animals' health is finally determined, from the natural point of view, there are no rational reasons to close the insulated roofs to animal habitation.

It is rather rare that the roof cavities are insulated with styrofoam pellets. In such cases, all roof access openings must be securely closed, because the pellet substrate is not stable and causes the animals to "drown" (the effect resembles drowning in quicksand). Because some birds force their way in by removing protective screens baring the roof access, the use of styrofoam pellets for the roof thermal insulation is not recommended.

Similar solutions exist for the bats that inhabit various cracks and crevices in the building walls. In this case, a special plate with a hole leading into a crack or crevice is installed on the wall, while the rest of the wall is thermally insulated and plastered. As a result, in the insulated wall only a small inlet opening is visible. Such solutions, however, are used very rarely.

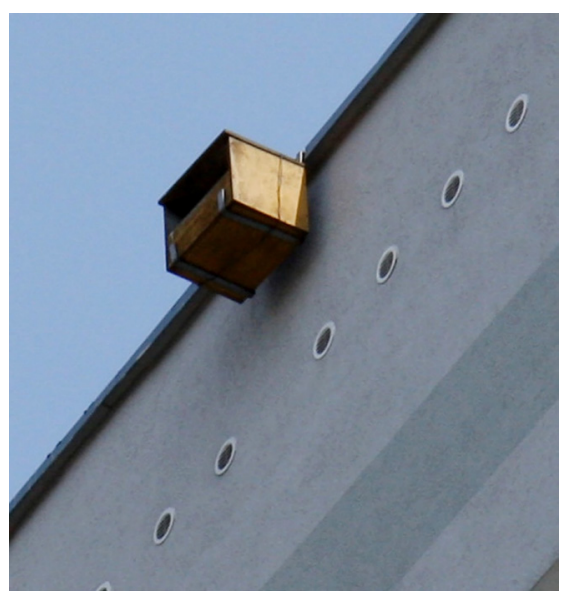

Fig. 2. Wooden nesting box for Kestrel suspended from the building roof as a part of compensation project

NESTING BOXES. Leaving the animal habitats intact is not always possible. This is especially true in situations where wall cracks or crevices which are either hard to reach or threaten the durability and integrity of the building structure must be filled thus resulting in the destruction of animal habitat. Installation of nesting boxes for birds and bats is the most common method of compensation for destroyed habitats in buildings [22]. This solution is a compromise between what is best for animals and the building owner's reluctance toward the "wildlife squatters". Nesting boxes are more expensive to install and less beneficial for birds and bats. Animals must get accustomed to a new place, the box material and limited space, so it happens that they leave their previously used long term habitats. Wooden boxes (Fig. 2) are relatively inexpensive, but have little resistance to external weather conditions, and therefore they need to be replaced every few years. To delay the decay process the wood material should be impregnated with a suitable and non-toxic solution, and the box roofs covered with asphalt shingles or sheet metal [27].

It is important to ensure the boxes for bats provide a good grip on all of their internal and external surfaces such as through the use of not planed, rugged and rough wood. Sawdust concrete boxes (Fig. 3, 4 and 5) are more durable than wooden boxes, but several times more expensive. 

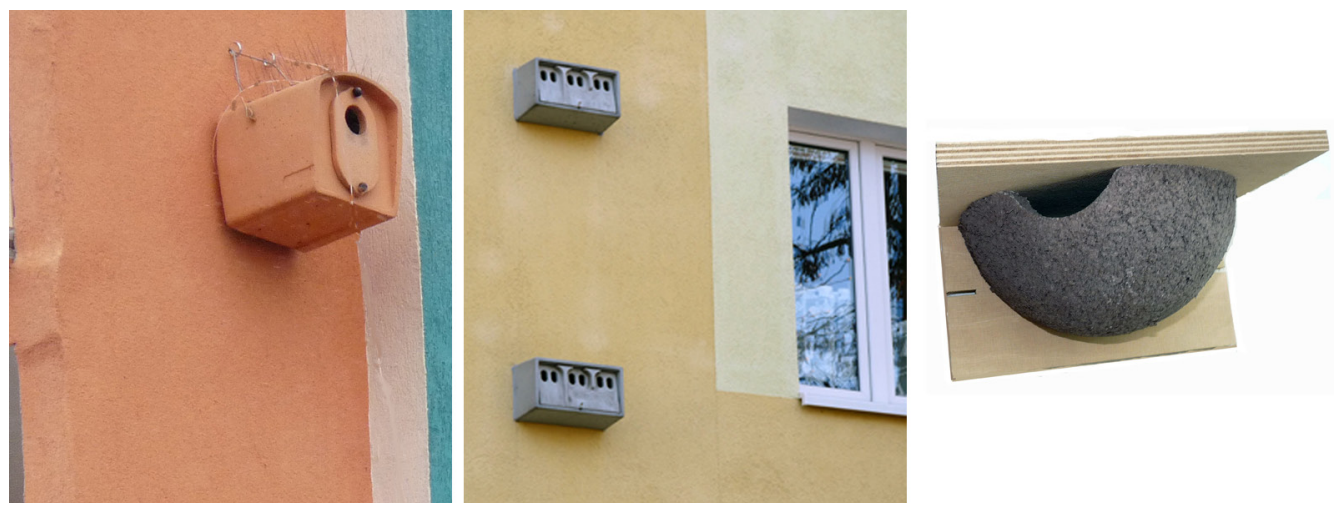

Fig. 3, 4 and 5. Sawdust concrete nesting boxes for Jackdaw (left), Sparrow (center) and House Martin (right)

All nesting boxes incur additional maintenance costs as they require periodic cleaning. Due to their relatively small capacity they quickly fill up with nesting materials, the remains of dead animals or other litter which has to be periodically removed. There are different types of nesting boxes for each species or groups of species (Fig. 6). The boxes differ primarily in the dimensions of their inlets, for example for Swift the inlet dimensions are $3.5 \mathrm{~cm} \times 6.5 \mathrm{~cm}, 8-9 \mathrm{~cm}$ for Jackdaw, $16-19 \mathrm{~cm} \times 40 \mathrm{~cm}$ for Kestrel, $3.3 \mathrm{~cm}$ for Sparrow [12], the gap height of $3-5 \mathrm{~cm}$ for bats 2008 [27].
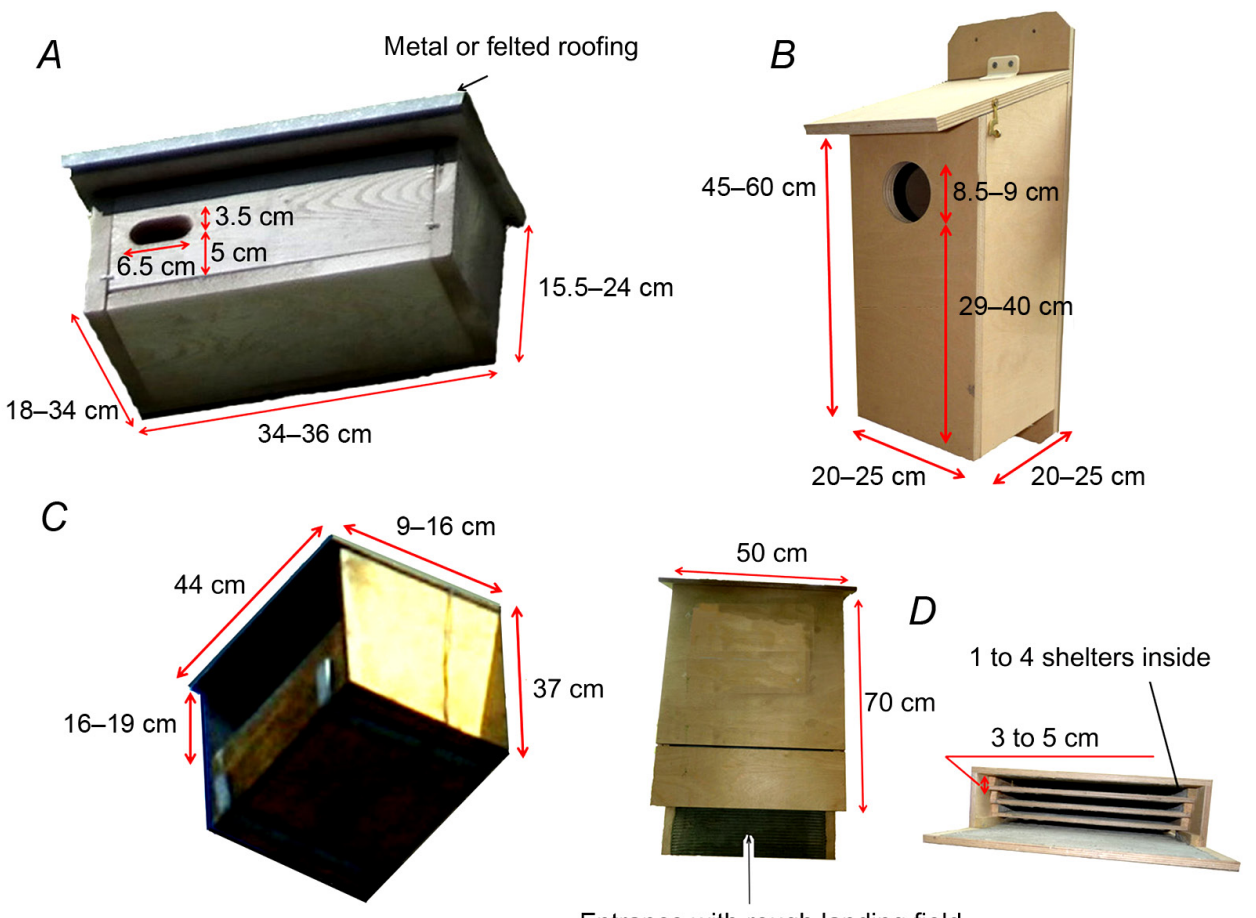

Entrance with rough landing field

Fig. 6. Examples of wooden nesting boxes with dimensions. Used for: $A-S$ wifts, $B-$ Jackdaws, $C-$ Kestrels, $D-$ Bats 
Boxes for individual species are mounted at different minimum heights, for example: for Sparrow at $3 \mathrm{~m}$, for Jackdaw at $5 \mathrm{~m}$, for Kestrel at $15 \mathrm{~m}$, for Swift at $5 \mathrm{~m}$ [12]. It is also important to maintain appropriate density of installed boxes. For animals that live in colonies such as sparrows and swifts the nesting boxes can hang in groups next to each other, and for territorial birds such as kestrel, individually. Care should also be exercised to avoid the installation of nesting boxes in their close proximity for predators and their prey such as Kestrels and Sparrow [27]. To increase the likelihood of settlement, the nesting boxes should be installed as close to the animals' previously occupied habitat as practically possible (Fig. 7). They can be hung directly on a newly insulated building wall or inserted into the thermal insulation layer (Fig. 7, 8). The second installation method is more aesthetic and provides greater durability [15, 27]. It also provides thermal conditions suitable for hibernating bats. However with this installation method, means should be provided to open the bird nesting boxes for a periodic cleaning while the bat boxes should be fitted with ramps to facilitate their self-cleaning (Fig. 9).

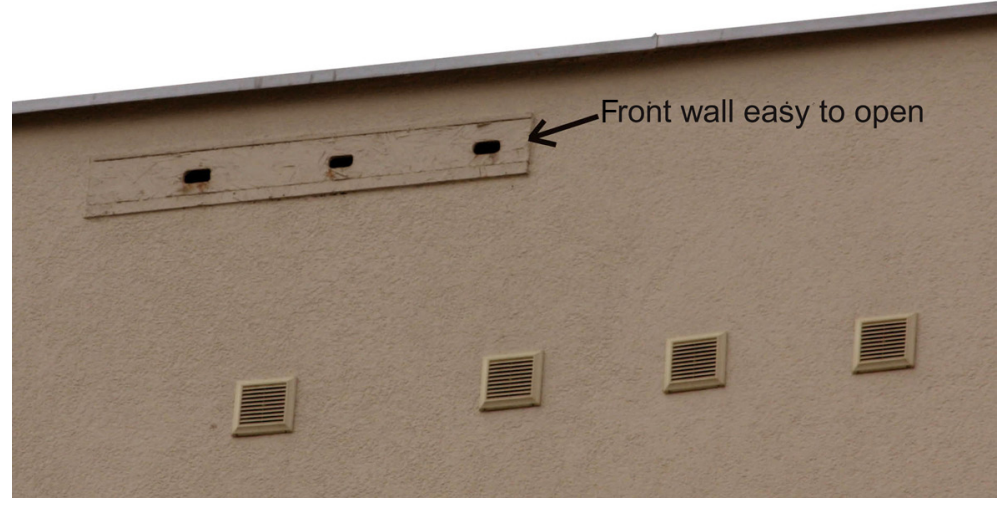

Fig. 7. Example of well planned compensation for bats and birds on the building's wall

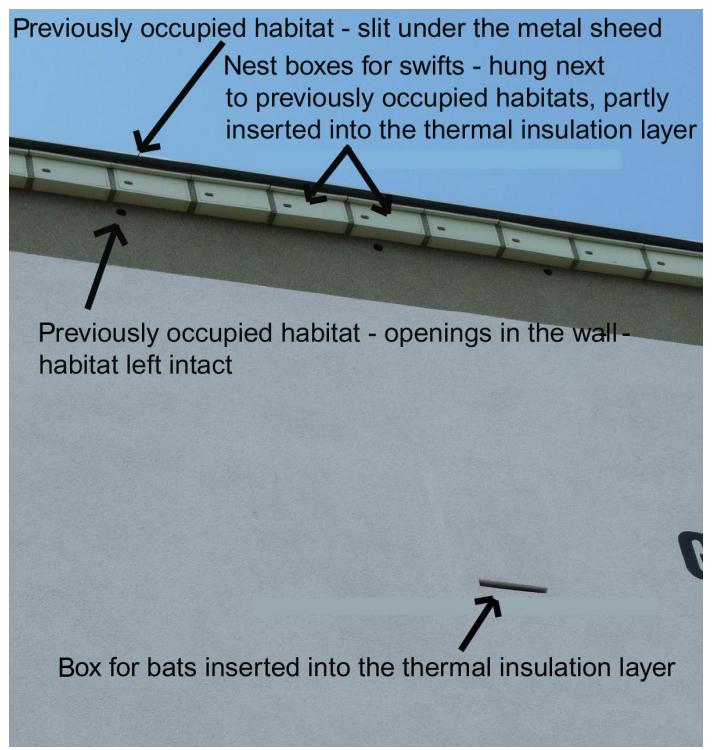

Fig. 8. Nesting boxes for Swift inserted into thermal insulation layer. Removable front partition allows for periodic cleaning of nesting boxes

ISSN 1996-4536 (print) • ISSN 2311-0783 (on-line) • Біологічні Студії / Studia Biologica • 2014 • Том 8/№1 • C. $205-216$ 

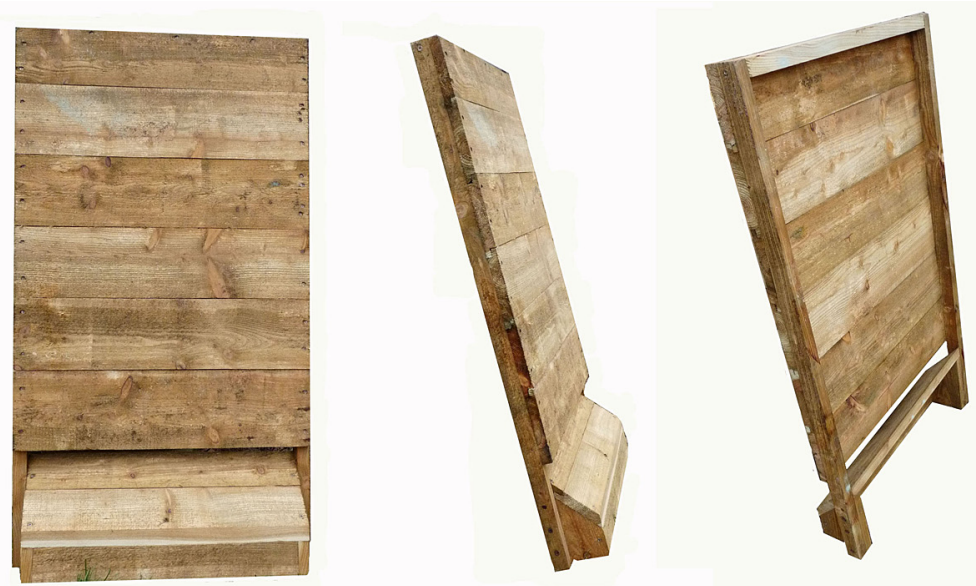

Fig. 9. Self-cleaning box for bats for insertion into thermal insulation layer: front (left), side (center), back (right)

The effectiveness of compensation in the form of nesting boxes varies for each species. However, there is not much data available which deals with this subject. From my initial observations in Bydgoszcz it appears that properly installed boxes for Jackdaw and Swift are readily colonized, but due to errors in the compensating recommendations its effectiveness is low for Sparrow. In Olsztyn the effectiveness of compensation for Swift was reported at zero [9]. This could be caused by mistake made by ornithologists who recommended the wrong placement for the boxes, for example too far from the previously occupied habitat. Such errors have been reported in Zielona Góra, where the nesting boxes for swifts were hung on the chimney wall less than $1 \mathrm{~m}$ above the roof (Fig. 10), while minimum of $5 \mathrm{~m}$ over the horizontal surface is recommended for this species. On the other hand, if the compensation is well planned, the birds inhabit the nesting boxes soon. In Wroclaw - Popowice [18] reported the very high number of boxes occupied by Kestrel - within two years all of the 20 installed boxes were inhabited.

Fig. 10. Nesting boxes for swifts hung too low above the roof. There is no chance on their inhabiting by swifts

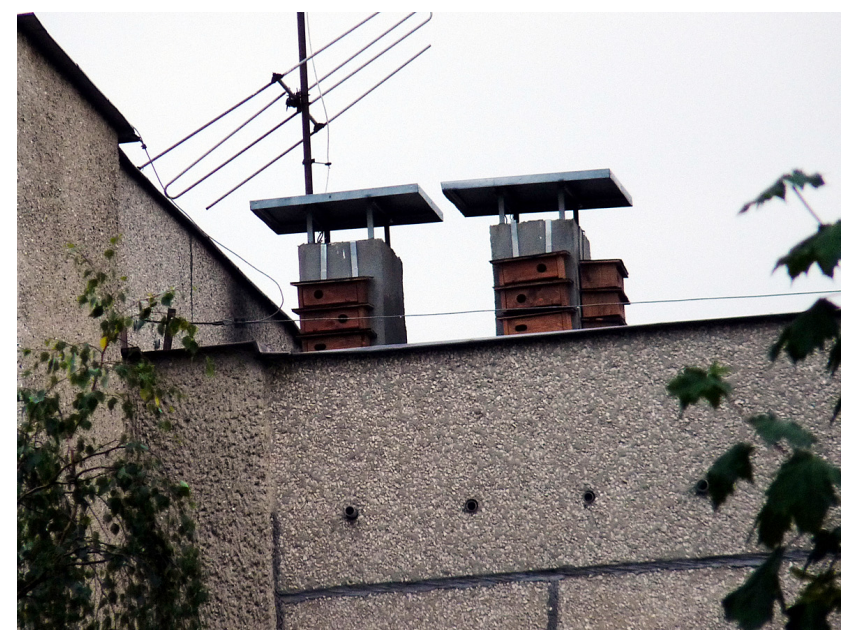




\section{SUMMARY}

Although the Polish law requires a building owner to carry out the renovations in accordance with the principles of environmental protection and perform compensation for destroyed animal habitats, the knowledge, understanding and respect for the law among building owners and managers is still insufficient. Therefore, there are both the non-governmental organizations [18] and individual professionals [6] operating in many cities throughout the country, who are involved in implementation of projects aimed at protection of birds and bats in buildings. Unfortunately, quite often a large part of their work involves interventions [14] in cases where renovation work is carried out without a permit, takes place during the birds or bats breeding season, when young and parents are bricked up alive in their habitats or thrown out from them. The non-governmental organizations play an important role in education of building managers, contractors and government officials, as well as in creation of practical work guidelines for carrying renovations in buildings inhabited by wildlife. Animal protection in buildings is a relatively new subject matter, however very rapidly growing. Compensation solutions continue to be inconsistent and not always effective. Currently, there is an urgent need for the verification of compensating solutions and the rapid introduction of appropriate changes, as in Bydgoszcz and in many other Polish cities most buildings have already been thermally insulated. Meanwhile, more buildings are being renovated and ineffective compensation methods reproduced.

1. Anderwald D., Sielicki S., Lontkowski J., Sielicki J. Sokół wędrowny w lasach. Włocławek: Stowarzyszenie „Sokół”, 2010. 28 p.

2. Betleja J. Pustułka Falco tinnunculus: In: Sikora A., Rohde Z., Gromadzki M., Neubauer G., Chylarecki P. (Ed.) Atlas rozmieszczenia ptaków lęgowych Polski 1985-2004. Poznań: Bogucki, 2007. $160 \mathrm{p}$.

3. Błażejewski P., Marcinowski J. Stalowa wieża na skrzynki lęgowe dla jerzyków Apus apus. In: Jerzak L., Tryjanowski P. (Ed.) Konferencja naukowa "Ptaki Miast" - Zielona Góra, 14-16 września 2012. Abstrakty. Zielona Góra: SOPTZool., 2012. 5 p.

4. Chiquet C., Dover J.W., Mitchell P. Birds and the urban environment: the value of green walls. Urban Ecosystems, 2012: 453-462.

5. Czechowski P., Bocheński M., Ciebiera O. Spadek liczebności kawki Corvus monedula w Zielonej Górze. In: Jerzak L., Tryjanowski P. (Ed.) Konferencja naukowa "Ptaki Miast" Zielona Góra, 14-16 września 2012. Abstrakty. Zielona Góra: SOPTZool, 2012. 10 p.

6. Dolata P. Ochrona ptaków w miastach - jak korzystać z prawa. In: Jerzak L., Tryjanowski P. (Ed.) Konferencja naukowa "Ptaki Miast" - Zielona Góra, 14-16 września 2012. Abstrakty. Zielona Góra: SOPTZool., 2012. 11 p.

7. Dolata P., Kamiński P., Winiecki A. Kawka Corvus monedula w Polsce - przegląd badań. In: Jerzak L., Kavanagh B.P., Tryjanowski P. (Ed.) Ptaki krukowate Polski. Poznań: Bogucki, 2005: 65-88.

8. Dubiec A. Kawka Corvus monedula. In: Sikora A., Rohde Z., Gromadzki M., Neubauer G., Chylarecki P. (Ed.) Atlas rozmieszczenia ptaków lęgowych Polski 1985-2004. Poznań: Bogucki, 2007. 160 p.

9. Duliusz B., Nowakowski J.J. Zasiedlenie budek lęgowych na budynkach po modernizacji. In: Jerzak L., Tryjanowski P. (Ed.) Konferencja naukowa "Ptaki Miast” - Zielona Góra, 14-16 września 2012. Abstrakty. Zielona Góra: SOPTZool., 2012. 13 p.

10. Dzięgielewska M., Dzięgielewski K. Zimowe kryjówki borowców wielkich w aglomeracji miejskiej. Nietoperze, 2002; 3(2): 299-300.

ISSN 1996-4536 (print) • ISSN 2311-0783 (on-line) • Біологічні Студії / Studia Biologica • 2014 • Том 8/№1 • C. $205-216$ 
11. Frieske A. Przyczyny zmian miejsc gnieżdżenia oknówki Delichon urbicum w peryferyjnej dzielnicy Bydgoszczy (Osowa Góra) w latach 2008-2012. In: Jerzak L., Tryjanowski P. (Ed.) Konferencja naukowa "Ptaki Miast" - Zielona Góra, 14-16 września 2012. Abstrakty. Zielona Góra: SOPTZool., 2012. 14 p.

12. Grzeniewski M., Kowalski M. Ochrona ptaków gniazdujących w budynkach. Warszawa: TP „Bocian”, 2010. 20 p.

13. Indykiewicz P. Ochrona kolonii lęgowych jerzyka Apus apus w budynkach poddanych pracom termomodernizacyjnym. In: Indykiewicz P., Jerzak L., Barczak T. (Ed.) Fauna Miast. Ochronić różnorodność biotyczną w miastach. Bydgoszcz: SAR "Pomorze", 2008. P. 96-102.

14. Janic B.. Działania interwencyjne związane z ochrona pustułki Falco tinnunculus w Łodzi. SiM, 2009; 3(22): 156-158.

15. Kasprzyk K., Tomaszewski M. Nowe skrzynki z trocinobetonu dla nietoperzy. In: Jaros R., Szubert-Kruszyńska A. (Ed.) XXI Ogólnopolska Konferencja Chiropterologiczna. Sieraków, 24-26 października 2008. Materiały konferencyjne. Poznań: PTOP "Salamandra", 2008: 46-47.

16. Lesiński G. Najliczniejsza w Polsce kolonia mroczka pozłocistego Eptesicus nilssonii. Nietoperze, 2004; 5(1-2): 117-118.

17. Lesiński G., Fuszara E., Kowalski M. Charakterystyka miejskiego zgrupowania nietoperzy Warszawy. Nietoperze, 2001; 2(1): 3-17.

18. Lontkowski J. Czynna ochrona pustułki Falco tinnunculus w Polsce. SiM, 2009; 3(22): 152155.

19. Luniak M. Ochrona kawki Corvus monedula wobec modernizacji budownictwa. In: Jerzak L., Tryjanowski P. (Ed.) Ptaki krukowate Polski. Poznań: Bogucki, 2005: 299-312.

20. Luniak M. Ochrona ptaków a modernizacja budownictwa. In: Indykiewicz P., Jerzak L., Barczak T. (Ed.) Fauna Miast. Ochronić różnorodność biotyczną w miastach. Bydgoszcz: SAR "Pomorze", 2008: 90-95.

21. Marnell F., Presetnik P. Protection of overground roosts for bats. Bonn: EUROBATS, 2010. (4): $57 \mathrm{p}$.

22. Sachanowicz K., Wower A. Poznajemy i chronimy nietoperze w miastach konurbacji śląsko-dąbrowskiej. Katowice: CDPGŚ, 2011. 32 p.

23. Szurlej-Kielanska A. Birds of selected areas in Świdnica (Poland). In: Urban Fauna - Studies of animal biology, ecology and conservation in European cities. Abstracts. Indykiewicz P., Böhner J. Bydgoszcz: UoTaLS, 2011. 74 p.

24. Van Oudheusden R. A call for help. Vocal behaviour of the Common Swift Apus apus. Haren: Groningen University, 2006. 39 p.

25. Vintchevski D., Sakowicz S. Pustułka Falco tinnunculus w Grodnie (zachodnia Białoruś). In: Jerzak L., Tryjanowski P. (Ed.) Konferencja naukowa "Ptaki Miast" - Zielona Góra, 14-16 września 2012. Abstrakty. Zielona Góra: SOPTZool, 2012. 28 p.

26. Węgrzynowicz A. Populacja wróbla i mazurka w Warszawie - liczebność, zmiany oraz uwarunkowanie dostępnością miejsc gniazdowych. In: Jerzak L., Tryjanowski P. (Ed.) Konferencja naukowa „Ptaki Miast” - Zielona Góra, 14-16 września 2012. Abstrakty. Zielona Góra: SOPTZool, 2012. 30 p.

27. Wylegała P., Dzięciołowski R., Jaros $R$. Standardy montowania ukryć dla ptaków i nietoperzy jako element prac dociepleniowych. Poznań: PTOP "Salamandra", 2008. 14 p.

28. Zielińska $D$. Wieże dla jerzyków Apus apus w Warszawie. In: Jerzak L., Tryjanowski P. (Ed.) Konferencja naukowa "Ptaki Miast" - Zielona Góra, 14-16 września 2012. Abstrakty. Zielona Góra: SOPTZool, 2012. 38 p.

29. Zieliński P. Jerzyk Apus apus: In: Sikora A., Rohde Z., Gromadzki M., Neubauer G., Chylarecki P. (Ed.) Atlas rozmieszczenia ptaków lęgowych Polski 1985-2004. Poznań: Bogucki, 2007. 160 p.

ISSN 1996-4536 (print) • ISSN 2311-0783 (on-line) • Біологічні Студії / Studia Biologica • 2014 • Том 8/№1 • С. 205-216 


\section{ЗАХИСТ ПТАХІВ І КАЖАНІВ У БУДІВЛЯХ, В ЯКИХ ЗДІЙСНЮЮТЬСЯ ТЕРМОІЗОЛЯЦІЙНІ ЗАХОДИ, - ПІДХОДИ ТА ДОСВІД У ПОЛЬЩ}

\section{Кароліна Ямська}

Бидгощська Група Загальнонаціонального Товариства Охорони Птахів вул. Беліцька, 1/20, 85-135 Бидгощ, Польща

Завдяки прогресивній деградації природного середовища, дедалі більше видів тварин пристосовуються до життя в антропогенних умовах. Деякі тварини так добре пристосувалися до нових умов, що відбувається зростання їх популяцій і збільшуються території поширення. Деякі птахи і кажани, які використовують житлові будинки як місця для гніздування, розмноження та зимової сплячки, є прикладом цієї успішної адаптації. В останні роки старі будинки, які мали багато щілин і отворів, привабливих для тварин, були інтенсивно відремонтовані й модернізовані. Внаслідок цього птахи і кажани, хоча й охороняються законом, втратили свої оселища, що, у свою чергу, поставило під загрозу стабільність їх популяцій. Отже, існує актуальна проблема захисту диких видів тварин і їх оселищ у житлових будинках. У результаті досліджень розроблено стандарти і практичні рекомендації для планування та реалізації ремонтно-будівельних робіт, а також розроблено відповідні рішення по компенсаціях для кожного виду. Метою цієї роботи є отримання базових знань і досвіду в захисті тварин у житлових будинках польських міст.

Ключові слова: кажани і птахи в житлових будинках, термоізоляція будинків, захист птахів і кажанів.

\section{ЗАЩИТА ПТИЦ И ЛЕТУЧИХ МЫШЕЙ В ЗДАНИЯХ, В КОТОРЫХ ПРОВОДЯТСЯ ТЕРМОИЗОЛЯЦИОННЫЕ МЕРОПРИЯТИЯ, - ПОДХОДЫ И ОПЫТ В ПОЛЬШЕ}

Каролина Ямская

Быдгощская Группа Общенационального Общества Охраны Птиц ул. Белицкая, 1/20, 85-135 Быдгощ, Польша

Благодаря прогрессирующей деградации природной среды, все больше видов животных приспособляется к жизни в антропогенных условиях. Некоторые животные так хорошо приспособились к новым условиям, что происходит возрастание их популяции и увеличиваются территории распространения. Некоторые птицы и летучие мыши, которые используют жилые дома для гнездования, размножения и зимней спячки, - пример этой успешной адаптации. В последние годы старые дома, с множеством щелей и отверстий, которые так привлекательны для животных, были интенсивно отремонтированы и модернизированы. Вследствие этого охраняемые законом птицы и летучие мыши потеряли свои жилища, что, в свою очередь, стало угрожать стабильности их популяций. Таким образом, имеется актуальная проблема защиты диких видов животных и их жилищ в жилых домах. В результате исследований разработаны стандарты и практические рекомендации для планирования и реализации ремонтно-строительных работ, а также соответствующие решения по компенсации для каждого вида. Цель этой работы - получение базовых знаний и опыта в защите животных в жилых домах польских городов.

Ключевые слова: летучие мыши и птицы в жилых домах, термоизоляция домов, защита птиц и летучих мышей.

Одержано: 3.12 .2013

ISSN 1996-4536 (print) • ISSN 2311-0783 (on-line) • Біологічні Студії / Studia Biologica • 2014 • Том 8/№1 • C. $205-216$ 